\title{
Selection of sub clover cultivars for New Zealand dryland pastures
}

\author{
R.J. LUCAS, A. MILLS, S. WRIGHT, A.D. BLACK and D.J. MOOT \\ Field Research Centre, Faculty of Agriculture \& Life Sciences, PO Box 85084 \\ Lincoln University, Lincoln 7647, New Zealand
}

Richard.Lucas@lincoln.ac.nz

\begin{abstract}
New Australian-bred cultivars of subterranean (sub) clover with high levels of hardseededness are being promoted in New Zealand based on their superior performance in Australia. These new cultivars may not be suited to cooler New Zealand conditions. The "soft" seeded sub clover 'Denmark' dominated the hardseeded cultivar 'Rosabrook' in the second year of a dryland grazing experiment near Lincoln $(630 \mathrm{~mm}$ mean annual rainfall), but in autumn of the third year the 'Rosabrook' population recovered to contribute 30\% of total sub clover plants. A second field experiment, sown in March 2014 at Lincoln University, compared 10 sub clover cultivars sown with cocksfoot. 'Antas', 'Narrikup' and 'Woogenellup' were most productive at the September 2014 harvest. 'Antas', 'Woogenellup' and 'Leura' had the highest dry matter yields at the November 2014 harvest. In autumn 2015 'Narrikup' re-established most seedlings and 'Antas' the least. Until we have better knowledge of the production and persistence of "new" sub clover cultivars under New Zealand conditions, farmers are urged to sow binary mixtures (50:50) of a "new" plus an "older" cultivar.
\end{abstract}

Keywords: cocksfoot, Dactylis glomerata, grazing experiment, hardseededness, re-establishment, Trifolium subterraneum

\section{Introduction}

The annual subterranean (sub) clover (Trifolium subterraneum L.) is the best adapted clover for inclusion in grass-based perennial pastures in New Zealand dryland regions where the white clover (Trifolium repens) does not persist because of regular summer droughts. In areas with shorter, less frequent, summer dry periods sub clover can provide a valuable complement to white clover.

There are large differences between sub clover cultivars, so the choice of well adapted cultivars is vital for the success of pasture improvement programmes. Sub clover cultivars differ in their flowering dates, burr burial ability, hardseededness, winter productivity, tolerance of wet soils, growth form and disease and pest tolerance (Table 1). In New Zealand we are reliant on cultivars which have been selected for Australian conditions and all seed is imported from Australia.
There has been a significant effort (Dodd et al. 1995a) to select adapted strains of sub clover for New Zealand conditions but none have, as yet, been commercialised. At a cool dry site in Canterbury, Widdup \& Pennell (2000) included several selections from Whatawhata and Palmerston North in their comparison of over 100 breeders' lines and cultivars and at least one was equal to the two best Australian cultivars, 'Denmark' and 'Leura'. Results from a similar comparison at a moist Whatawhata, North Island, site favoured the local selections, 'Tallarook' and 'Denmark' (Dodd et al. 1995b).

Historically, and currently, the range of sub clover cultivars available to New Zealand farmers has been influenced by the Australian seed harvest and its availability for export. Plant Variety Rights, trans-Tasman seed company loyalties, New Zealand biosecurity issues with weed seed and soil contamination and the perception that the New Zealand market for sub clover seed is not large enough to bother with, have been important influences on sub clover imports. Hence, selection of cultivars for the New Zealand market has often not been based on evidence from local field experiments. For instance, Smetham (2003) referred to the early work by Levy \& Gorman (1936) who reported that dry matter (DM) yields from 'Mt Barker' and 'Tallarook' were exceeded by other cultivars. However, seed of only those two cultivars was commercially available at the time. Consequently, 'Mt Barker' in particular has become widespread throughout the country as a result of oversowing and top dressing from the 1930s to the 1960s (Smetham 2003).

It seems that the early importation of 'Mt Barker' was, however, fortuitous as it has proved to be well adapted across dryland pastoral environments. Over time, under New Zealand environmental conditions and grazing management, 'Mt Barker' and 'Tallarook' have adapted to local conditions (Macfarlane \& Sheath 1984). Sub clover cultivar comparisons, which were conducted over a wide range of sites during the 1980 s, showed that 'Mt Barker' and the very late flowering 'Tallarook' were superior at most of the eight sites (Chapman et al.1986). 'Tallarook' flowered too late to set sufficient seed at the driest site (600 $\mathrm{mm}$ annual rainfall). At the wettest site selections of T. subterraneum subspecies yanninicum 
were well adapted. Macfarlane et al. (1990) tested a range of cultivars on 21 farms in the northern North Island and also concluded that 'Tallarook' and 'Mt Barker' types were best adapted. They concluded that "until new cultivars with Tallarook-type characteristics become available Tallarook and Mt Barker are the only sub clover cultivars that can be recommended for introduction into North Island hill country".

The most recent evaluation of sub clover cultivars in New Zealand included a large number of imported seed lines and some New Zealand selections (Widdup $\&$ Pennell 2000). This experiment was conducted over 4 years from 1993 at Templeton in Canterbury $(620 \mathrm{~mm}$ annual rainfall), which is drier than most of the sites in the previous comparisons. 'Denmark' and 'Leura' were the best named cultivars with outstanding seed set and DM productivity. Table 1 presents characteristics of most of the cultivars which have been imported into New Zealand over recent years (Nichols et al. 2013). Several of the pre-1999 cultivars listed in Table 1 were included in the Templeton experiment (Widdup \& Pennell 2000).
Some of the cultivars first commercialised since 1999 and imported into New Zealand over the last 15 years are currently being promoted as superior options which have "superseded" older cultivars.

This paper describes some preliminary findings from two on-going investigations under dryland conditions in Canterbury. The general aim for the early publication of these results is to draw attention to the possibility that "new" cultivars which were not included in the Widdup \& Pennell (2000) evaluation may not be suitable for some New Zealand environments.

Specific objectives were:

1). Experiment 1: The "MAXannuals" grazing experiment at Ashley Dene compared four pasture mixtures based on sub clover. These were established with or without balansa clover (Trifolium michelianum) sown with either cocksfoot (Dactylis glomerata) or ryegrass $\mathrm{X}$ fescue hybrid (Festulolium) as the companion grass in March 2013. It provided an opportunity to compare 'Denmark' (commercial release 1992) with 'Rosabrook' (commercial release 2009) by sowing a

Table 1 Agronomic data for Australian subterranean clover cultivars which have been sown in New Zealand. Data from long-term means of irrigated plants from an early May sowing in Perth, Western Australia (adapted from Nichols et al. 2013). Seeds sown $/ \mathrm{m}^{2}$ is a bare seed equivalent rate.

Year $=$ Year seed first sold/ date registered as an Australian cultivar.

Subspecies: B, brachycalycinum; S, subterraneum; Y, yanninicum.

Min. growing season length (months) is the minimum target environment for reliable seed set.

Burr burial: 1, little or no burial; 9 , strong burial.

Relative hardseededness: 1 , least hard; 10 , most hard, based on laboratory screening in a diurnally fluctuating $60 / 15^{\circ} \mathrm{C}$ temperature cabinet for 16 weeks, using the procedure of Quinlivan \& Millington (1962).

\begin{tabular}{|c|c|c|c|c|c|c|c|}
\hline Cultivar & Year & Subspecies & $\begin{array}{l}\text { Days to } \\
\text { first } \\
\text { flower }\end{array}$ & $\begin{array}{l}\text { Min. growing } \\
\text { season } \\
\text { length (months) }\end{array}$ & $\begin{array}{c}\text { Burr } \\
\text { burial rating } \\
\text { (1-9 rating) }\end{array}$ & $\begin{array}{c}\text { Hard- } \\
\text { seededness } \\
(1-10)\end{array}$ & $\begin{array}{l}\text { Seeds } / \mathrm{m}^{2} \\
\text { sown } \\
\text { at } 10 \mathrm{~kg} / \mathrm{ha}\end{array}$ \\
\hline Mt Barker & 1900 & $\mathrm{~S}$ & 137 & 7.5 & 3 & 1 & 120 \\
\hline Tallarook & 1936 & $S$ & 163 & 9 & 5 & 1 & 135 \\
\hline Woogenellup & 1959 & $S$ & 130 & 7 & 3 & 1 & 93 \\
\hline Seaton Park & 1967 & $S$ & 110 & 5 & 7 & 5 & 110 \\
\hline Trikkala & 1975 & $\mathrm{Y}$ & 112 & 5.5 & 6 & 2 & 81 \\
\hline Karridale & 1985 & $\mathrm{~S}$ & 139 & 7.5 & 6 & 2 & 127 \\
\hline Denmark & 1992 & $\mathrm{~S}$ & 142 & 7.5 & 5 & 2 & 141 \\
\hline Leura & 1992 & $S$ & 147 & 8 & 5 & 2 & 135 \\
\hline Goulburn & 1992 & $S$ & 141 & 7 & 5 & 5 & 196 \\
\hline Gosse & 1992 & $\mathrm{Y}$ & 126 & 7 & 5 & 3 & 91 \\
\hline Antas & 1999 & B & 138 & 7.5 & 1 & 3 & 100 \\
\hline Campeda & 1999 & $\mathrm{~S}$ & 123 & 6 & 6 & 5 & 123 \\
\hline Napier & 2001 & $\mathrm{Y}$ & 140 & 7.5 & 6 & 5 & 88 \\
\hline Coolamon & 2003 & $\mathrm{~S}$ & 133 & 6.5 & 7 & 5 & 130 \\
\hline Narrikup & 2009 & $S$ & 126 & 6.5 & 7 & 3 & 185 \\
\hline Rosabrook & 2009 & $S$ & 142 & 7.5 & 6 & 5 & 161 \\
\hline Monti & 2013 & $\mathrm{Y}$ & 110 & 5.5 & 6 & 2 & 101 \\
\hline
\end{tabular}


50:50 mix of the two cultivars in all 16 half-hectare plots. The proportions of each sub clover cultivar in spring pastures over several years should indicate the relative merits of the two cultivars.

2). Cocksfoot $\times 10$ sub clover cultivars at Lincoln University. First year spring yields after March 2014 sowing and subsequent seedling regeneration in autumn 2015 , from the first natural seed set, will indicate sub clover cultivar capability when in competition with cocksfoot.

\section{Methods}

\section{Experiment 1 - Ashley Dene; "MAXannuals" grazing experiment}

Experiment 1 was established at Ashley Dene, Canterbury $\left(43^{\circ} 38^{\prime} \mathrm{S}, 172^{\circ} 19^{\prime} \mathrm{E}, 39 \mathrm{~m}\right.$ a.s.1.), in March 2013 as part of Phase II of the Pastoral 21 programme (Bray et al. 2013). The "MAXannuals" grazing experiment was established to evaluate four dryland pasture mixes on a Lismore very stony silt loam. The site of Reps 1 and 2 had been in ryegrass/sub clover pasture for the previous 10 years and the site of Reps 3 and 4 were in lucerne and then winter forage production for the past nine years. Rainfall and temperature data are reported in Table 2 and Figure 1.

The sown pastures included either cocksfoot (CF; 2 $\mathrm{kg} / \mathrm{ha} \mathrm{cv}$. 'Greenly') or ryegrass $\mathrm{x}$ fescue hybrid (RG; $10 \mathrm{~kg} / \mathrm{ha}$, breeders line) established with or without balansa clover (Bal; 0 or $4 \mathrm{~kg} / \mathrm{ha} \mathrm{cv}$. 'Bolta'). Basal pasture components, sown with all treatments, were 10 $\mathrm{kg} / \mathrm{ha}$ of sub clover $(5 \mathrm{~kg} / \mathrm{ha} \mathrm{cv}$. 'Denmark' $+5 \mathrm{~kg} / \mathrm{ha} \mathrm{cv}$.
'Rosabrook'), white clover ( $0.5 \mathrm{~kg} / \mathrm{ha} \mathrm{cv.} \mathrm{'Nomad')} \mathrm{and}$ plantain $(0.5 \mathrm{~kg} / \mathrm{ha}$ Plantago lanceolata $\mathrm{cv}$. 'Tonic'). There were four replicates and each plot was ca. 0.5 ha.

\section{Year 1 (2013)}

Plots were sown in late March and early April 2013 and allowed to establish before the first grazing when ewe hoggets were set stocked at 27 hoggets/ha in September and October 2013. All plots were then spelled for 8 weeks to allow the clovers to set seed from 21 October 2013 when pasture mass was over $1500 \mathrm{~kg} \mathrm{DM} / \mathrm{ha}$.

\section{Year 2 (2014)}

Plots were intensively grazed with ewes in late summer and autumn 2014 to a residual pasture mass of about $600 \mathrm{~kg} \mathrm{DM} /$ ha with about $30 \%$ bare ground plus litter. Eleven ewes/ha and their twin lambs were set stocked in September and then combined to be rotationally grazed on assigned pasture treatments during October. In spring, visual scores were taken of the proportions of sub clover cultivars in all 16 plots. Below average spring rainfall (Sept-Nov 2014, Table 2, Figure 1) compromised feed supply and the stocking rate was reduced to 5 ewes/ha and their twin lambs from 22 October. Pastures were completely destocked on 30 October. Dry ewes grazed the plots in summer $(28$ Nov-8 Jan) to a residual pasture mass of ca. $900 \mathrm{~kg}$ $\mathrm{DM} / \mathrm{ha}$. In late January 2014 the annual clover seedbank was quantified following completion of sub and balansa clover lifecycle. Clover seed yields were estimated by excavating $10 \times 0.01 \mathrm{~m}^{2}$ quadrats per plot to $3 \mathrm{~cm}$ depth

Table 2 Monthly rainfall $(\mathrm{mm})$ and mean air temperature $\left({ }^{\circ} \mathrm{C}\right)$ monitored at Ashley Dene, Canterbury from Jan 2013 to May 2015. The long-term mean (LTM) rainfall is a 40-year mean (1970-2010) from the nearby Burnham monitoring site. Long-term mean monthly air temperatures are for the period 1980-2009 (CliFlo Station Agent No. 4880; http://cliflo.niwa.co.nz/).

\begin{tabular}{|c|c|c|c|c|c|c|c|c|}
\hline \multirow[b]{2}{*}{ Month } & \multicolumn{4}{|c|}{ Rainfall (mm) } & \multicolumn{4}{|c|}{ Mean Air Temperature $\left({ }^{\circ} \mathrm{C}\right)$} \\
\hline & 2013 & 2014 & 2015 & LTM & 2013 & 2014 & 2015 & LTM \\
\hline Jan & 40.8 & 18.0 & 25.8 & 44.5 & 17.6 & 15.9 & 17.8 & 16.6 \\
\hline Feb & 24.6 & 46.0 & 21.0 & 42.9 & 16.1 & 16.4 & 16.2 & 16.3 \\
\hline Mar & 40.8 & 120.4 & 56.0 & 49.8 & 15.8 & 13.8 & 15.3 & 14.6 \\
\hline Apr & 49.6 & 139.0 & 94.2 & 49.0 & 12.5 & 12.2 & 12.9 & 11.8 \\
\hline May & 91.6 & 31.2 & 5.2 & 65.0 & 9.6 & 9.8 & 9.4 & 9.2 \\
\hline Jun & 224.2 & 47.4 & & 62.1 & 7.0 & 8.0 & & 6.6 \\
\hline Jul & 36.2 & 31.6 & & 65.2 & 8.2 & 6.7 & & 6.1 \\
\hline Aug & 39.6 & 15.6 & & 69.6 & 9.4 & 7.3 & & 7.3 \\
\hline Sep & 38.8 & 19.0 & & 45.6 & 9.5 & 9.2 & & 9.4 \\
\hline Oct & 76.9 & 22.8 & & 50.3 & 12.4 & 11.2 & & 11.4 \\
\hline Nov & 33.4 & 37.8 & & 47.7 & 13.7 & 13.5 & & 13.1 \\
\hline Dec & 82.6 & 26.2 & & 49.6 & 16.0 & 15.5 & & 15.1 \\
\hline Annual & 779 & 555 & & 627 & & & & 11.5 \\
\hline
\end{tabular}




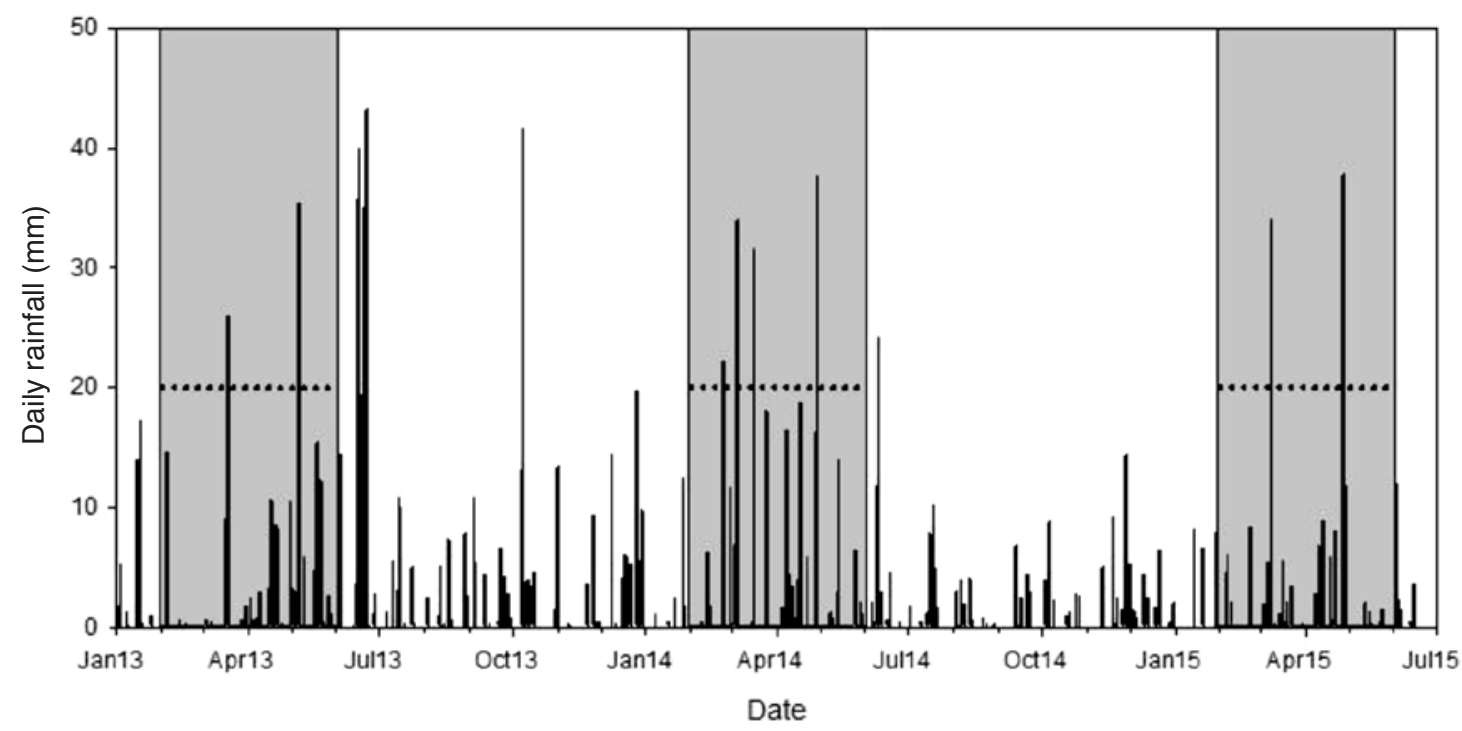

Figure 1 Daily rainfall at Ashley Dene from Jan 2013 to May 2015. Horizontal dotted lines are germination trigger values of $20 \mathrm{~mm}$ rainfall events. Grey shaded areas are the main period of sub clover germination (1 Feb to 30 May).

and washing and sieving out sub and balansa clover seeds from the soil plus herbage samples.

\section{Year 3 (2015)}

Dry ewes grazed from 16-28 February to pasture residuals of about $700 \mathrm{~kg} \mathrm{DM} / \mathrm{ha}$ and in autumn (8-28 April 2015) to a residual of $1200 \mathrm{~kg} \mathrm{DM} / \mathrm{ha}$. Mean bare ground in early April was 30\% in all pastures. In late May 2015, after their second natural regeneration, sub clover cultivar populations were identified in Reps 3 and 4. Measurements were not taken from Reps 1 and 2 due to potential confounding from previous presence of various sub clover cultivars. Annual clover seedlings germinated in early April but cultivars could not be distinguished until clear leaf markings were visible in late May.

Three methods were used to quantify the relative contribution of the 'Denmark' and 'Rosabrook' cultivars: i) approximately 50 seed burrs were collected from 10 random sites in early March 2015 from the soil surface of each plot in Replicate 4. Seeds from those burrs were sown in potting mix and grown in a glasshouse at about $18^{\circ} \mathrm{C}$. These seedlings were identified from leaf markings by early May 2015; ii) exclosure cages were placed in Reps 3 and 4 on 8 April 2014 prior to grazing to reduce grass competition on the establishing annual clover seedlings. There was sufficient growth of sub clover within the exclosure cages to allow seedling identification by leaf markings on 20 May; iii) on 26 May 2015, 20 random "snip" samples per plot of clover were cut from the grazed pasture area in each plot of Reps 3 and 4. Samples were bulked and clover species and cultivars were dissected, dried and weighed.
Experiment 2 - Lincoln University; cocksfoot $\times 10$ sub clover cultivars

A second experiment evaluated the performance of 10 sub clover cultivars established with cocksfoot as a companion grass at Lincoln University $\left(43^{\circ} 38^{\prime} \mathrm{S}\right.$, $172^{\circ} 27^{\prime} \mathrm{E}, 11 \mathrm{~m}$ a.s.l.) on Templeton silt loam soil. The site had been under an annual cropping regime for the previous six years. Long-term mean annual rainfall (1975-2013) was $632 \mathrm{~mm}$ and mean monthly air temperatures range from $6.1^{\circ} \mathrm{C}$ in July to $16.6^{\circ} \mathrm{C}$ in January. Rainfall and mean monthly air temperatures during the experimental period are reported in Figure 2.

Five replicates of a randomised block design were sown on 14 March 2014. Plots were $11 \mathrm{~m} \times 6.3$ m. Heavy rain from mid-March/April created wet conditions through winter (Table 2, Figure 1) which prevented herbicide application to control vigorous twin cress (Lepidium didymum) emergence after sowing. Yield and botanical composition were determined from two $0.2 \mathrm{~m}^{2}$ quadrats cut to $3 \mathrm{~cm}$ residual height on 23 September and 20 November 2014. Pastures were then grazed by sheep to a residual biomass of approximately $1000 \mathrm{~kg} \mathrm{DM} / \mathrm{ha}$. Cocksfoot seed heads were cut and removed from the area in December and the plots were grazed twice by ewes during summer to reduce cocksfoot competition. Rainfall at Lincoln totalled $614 \mathrm{~mm}$ in 2014 (1 Jan-31 Dec). In 2015 (1 Jan-30 Jun) rainfall was $227 \mathrm{~mm}$ compared with the long term mean for that period (Jan-Jun) of $307 \mathrm{~mm}$. Thus, to ensure sub clover germination occurred at the "normal" time, $25 \mathrm{~mm}$ of irrigation was applied with an Ocmus gun irrigator on 10 March 2015. Once germination began, seedling counts were made at 2-6 day intervals 


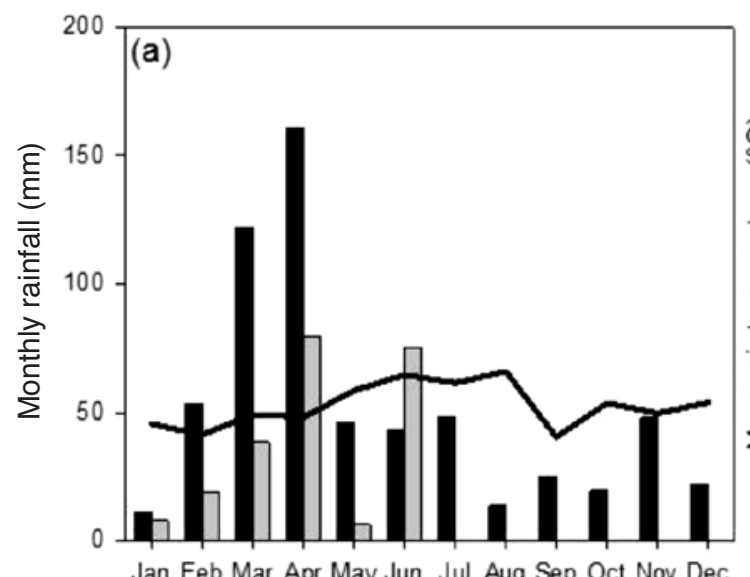

Jan Feb Mar Apr May Jun Jul Aug Sep Oct Nov Dec

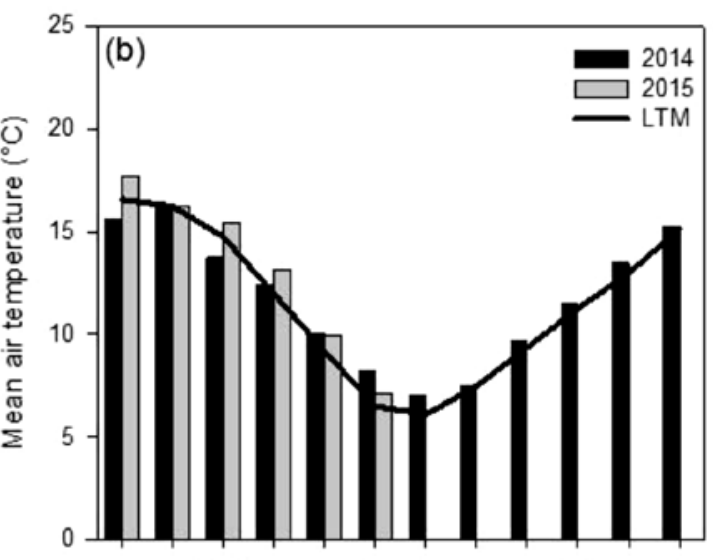

Jan Feb Mar Apr May Jun Jul Aug Sep Oct Nov Dec

Month

Figure 2 (a) monthly rainfall $(\mathrm{mm})$ and $(\mathrm{b})$ mean air temperature $\left({ }^{\circ} \mathrm{C}\right)$ between January 2014 and June 2015 recorded at the Broadfields Meteorological Station located $2 \mathrm{~km}$ northeast of the experimental area (CliFlo Station Agent No. 17603; http://cliflo.niwa.co.nz/). The longterm mean (LTM) is for the period 1975-2013.

between 23 March and 5 May from two $0.1 \mathrm{~m}^{2}$ pegged sites per plot.

\section{Statistical analysis}

Data were analysed in Genstat (version 16.1, VSN international Ltd) by ANOVA. Similar values are reported as means with their respective standard error of the mean (SEM). Means were separated by Fisher's protected LSD at $\alpha=0.05$ where significant.

\section{Results and Discussion}

\section{Experiment 1 - Ashley Dene; "MAXannuals" grazing experiment}

In 2013, pasture on offer to ewe hoggets in the first spring reflected the 50:50 ratio of 'Rosabrook':'Denmark' which was initially sown and there was no visual difference observed in the relative proportions of the two cultivars within each plot (data not presented). Table 3 shows the quantity of annual clover seed set after pastures were closed from grazing from 21 October 2013. Sub clover seed yield in late summer 2014 from grass plots was highest $(\mathrm{P}=0.039)$ from the $\mathrm{CF} / \mathrm{Sub}$ and $\mathrm{RG} / \mathrm{Sub}$ pastures $(717 \pm 93.4 \mathrm{~kg}$ seed/ha) and lowest from the $\mathrm{CF} / \mathrm{Sub} / \mathrm{Bal}$ pasture $(354 \mathrm{~kg}$ seed/ ha). Sub clover had a thousand seed weight (TSW) of $6.2 \pm 0.27 \mathrm{~g}$ and balansa seed had a TSW of $0.99 \pm 0.04$ g. Neither was affected by companion grass treatment.

After the first natural re-establishment in autumn 2014 the ratio of 'Denmark' to 'Rosabrook' seedlings was not assessed. However, in the following spring 'Denmark' dominated 'Rosabrook'. Visual observations based on leaf markings and corolla colour in late October/November indicated about $90 \%$ of the total sub clover forage on offer to ewes and lambs was 'Denmark' (data not presented).
Moderate populations of ca. 600 sub clover seedlings $/ \mathrm{m}^{2}$ established after autumn break rains of 2015. There were ca. 800 balansa seedlings $/ \mathrm{m}^{2}$ in pastures established with ryegrass and ca. 400 balansa seedlings $/ \mathrm{m}^{2}$ in cocksfoot-based pastures. The ratio of sub clover cultivar plant numbers from glasshouse grown seed samples was $70 \%$ 'Denmark' and $30 \%$ 'Rosabrook'. Botanical composition of exclosure cage samples showed $69 \%$ of sub clover DM was from 'Denmark' and 31\% was contributed by 'Rosabrook'. The random snip samples from the grazed pasture area showed 'Rosabrook' contributed $26 \pm 3.8 \%$ of the total sub clover present and did not differ $(\mathrm{P}=0.20)$ between pasture treatments. Over the three methods used, neither

Table 3 Subterranean (Sub) and balansa (Bal) clover seed $(\mathrm{kg} / \mathrm{ha})$ determined from seed recovered from $0-3 \mathrm{~cm}$ soil depth in January 2014 within pastures established with either cocksfoot (CF) or hybrid ryegrass (RG) at Ashley Dene, Canterbury. Pastures were initially established in autumn 2013.

\begin{tabular}{lcc}
\hline Pasture mix & Sub clover seed & Balansa clover seed \\
\hline CF/Sub & $713_{\mathrm{ab}}$ & - \\
CF/Sub/Bal & $354_{\mathrm{c}}$ & 1020 \\
RG/Sub & $721_{\mathrm{a}}$ & - \\
RG/Sub/Bal & $415_{\mathrm{bc}}$ & 723 \\
\hline Mean & 551 & 871 \\
SEM & 93.4 & 286.8 \\
Significance & $*$ & $\mathrm{~ns}$ \\
\hline
\end{tabular}

Note: ${ }^{*}=\mathrm{P}<0.05$ and $\mathrm{ns}=$ non-significant. SEM is standard error of the mean. Means followed by the same letter are similar at the $a=0.05$ level. 


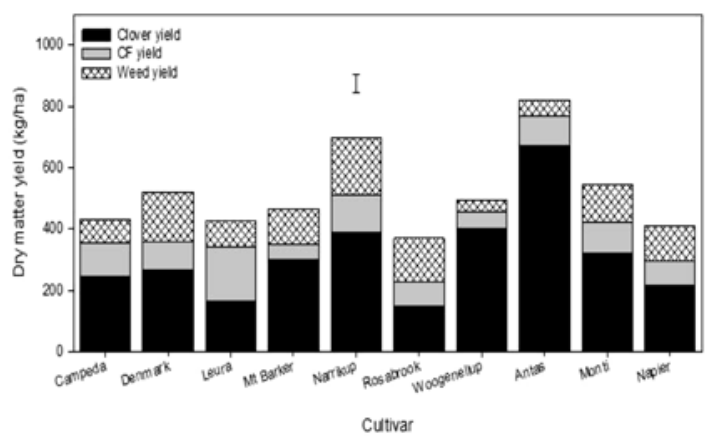

Figure 3 Dry matter yield $(\mathrm{kg} / \mathrm{ha})$ of sub clover cultivars, cocksfoot (CF) and weeds harvested in September 2014 at Lincoln University, Canterbury. The error bar is the SEM for total dry matter yield.

grass species nor balansa clover presence affected the ratio of sub clover cultivars which averaged $71 \%$ from 'Denmark' and 29\% from 'Rosabrook'.

The low contribution of 'Rosabrook' to 2014 spring herbage production and its apparent recovery in autumn 2015 may be attributed to a large carry-over of hard seed produced by 'Rosabrook' from the large seed set in spring 2013. This assumption is based on the hardseededness ratings from Nichols et al. (2013) under Western Australian conditions. 'Rosabrook' has a hardseededness rating of 5 while 'Denmark' is relatively "soft" seeded with a hardseededness rating of 2 (Table 1). Seed burrs cannot be easily distinguished between cultivars to test for hardseededness from these mixed pastures. Consequently, until detailed local measurements are conducted on monocultures of "new" sub clover cultivars which have been released over the last 15 years we will have to rely on Australian ratings.

\section{Experiment 2 - Lincoln University; Cocksfoot $\times 10$ sub clover cultivars}

In September 2014 (Figure 3), the highest $(\mathrm{P}<0.012)$ total DM yields were from 'Antas' and 'Narrikup' $(758 \pm 62.4 \mathrm{~kg} \mathrm{DM} / \mathrm{ha})$. 'Antas' was the most productive $(\mathrm{P}<0.001)$ sub clover in early spring $(670 \mathrm{~kg} \mathrm{DM} / \mathrm{ha})$. In general, late flowering cultivars such as 'Leura', 'Denmark' and 'Rosabrook' were lower yielding in September. 'Leura' and 'Narrikup' treatments had the highest $(\mathrm{P}<0.032)$ cocksfoot yield $(153 \pm 19.4 \mathrm{~kg} \mathrm{DM} /$ ha). Weed species contributed $109 \pm 28.5 \mathrm{~kg} \mathrm{DM} / \mathrm{ha}$ and their yield was unaffected by sub clover cultivar.

Total DM yield at the November harvest was 3524 $\pm 293 \mathrm{~kg} \mathrm{DM} / \mathrm{ha}$ and was similar $(\mathrm{P}=0.107)$ for all treatments (Figure 4). However, yield of the sub clover component was highest $(\mathrm{P}<0.001)$ from 'Woogenellup', 'Antas' and 'Leura' (2712 $\pm 243 \mathrm{~kg} / \mathrm{ha})$. 'Leura' was the only late flowering cultivar to overcome the spring grass and weed competition. The lowest sub clover yield at the November harvest was $1465 \pm 244 \mathrm{~kg} / \mathrm{ha}$

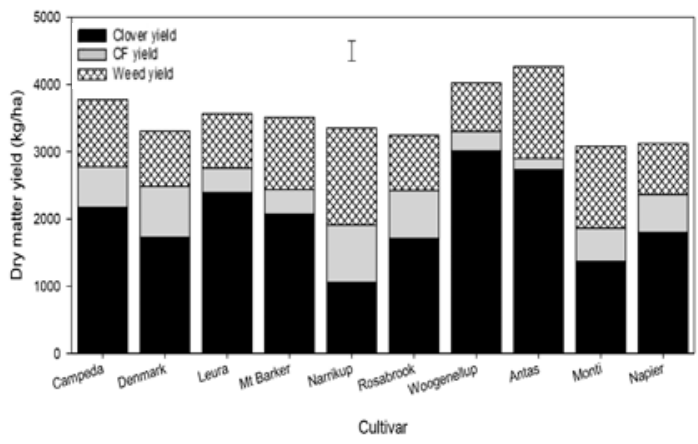

Figure 4 Dry matter yields $(\mathrm{kg} / \mathrm{ha})$ of sub clover cultivars, cocksfoot (CF) and weeds at the November harvest at Lincoln University, Canterbury. The error bar is the SEM for total dry matter yield.

from 'Denmark', 'Rosabrook', 'Monti' and 'Narrikup'. Cocksfoot yields ranged $(\mathrm{P}=0.007)$ from 162 ('Antas') to $853 \mathrm{~kg} \mathrm{DM} / \mathrm{ha}$ ('Narrikup'). Weed yield was not affected by treatment $(\mathrm{P}=0.274)$ and averaged $1003 \pm 231 \mathrm{~kg} \mathrm{DM} / \mathrm{ha}$ which accounted for $29 \pm 5.4 \%$ of the total DM yield in November. It was notable that the two yanninicum sub clover cultivars ('Monti' and 'Napier') did not stand out in this study as might have been expected given the wet soil conditions in winter.

An essential feature of sub clover cultivars is their ability to persist in mixed pastures. Figure 5 presents clover seedling populations established from each of the $10 \mathrm{sub}$ clover treatments in autumn 2015 during the first natural regeneration of the clovers. Seedling populations were relatively low and mean seedling numbers on 5 May 2015 ranged $(\mathrm{P}<0.017)$ from 31 ('Antas') to 293 seedlings $/ \mathrm{m}^{2}$ ('Narrikup'), but there was a high degree of variation observed (CV\% 87.9). Of the seven subterraneum subspecies cultivars, the high level of 'Narrikup' regeneration is notable in that it has a high rating for burr burial of 7 and a medium hard seed rating of 3 (Table 1). In contrast, the widely sown older cultivars, 'Woogenellup' and 'Mt Barker', had low seedling populations (78 and 47 plants $/ \mathrm{m}^{2}$ ). They both rate $1 / 10$ for hardseededness but only $3 / 9$ for burr burial ability. The very low seedling population established by 'Antas' can be attributed to its ineffective burr burial, which is a characteristic of the brachycalycinum subspecies of sub clover (Dear \& Sandral 1997).

\section{General Discussion}

The preliminary data presented in this paper illustrate the large differences between sub clover cultivars. Clearly the choice of which sub clover cultivar to sow is vital to creating productive and persistent sub clover dominant permanent pastures. However, the two experiments described are from one climatic area in lowland Canterbury monitored for two growth seasons. 


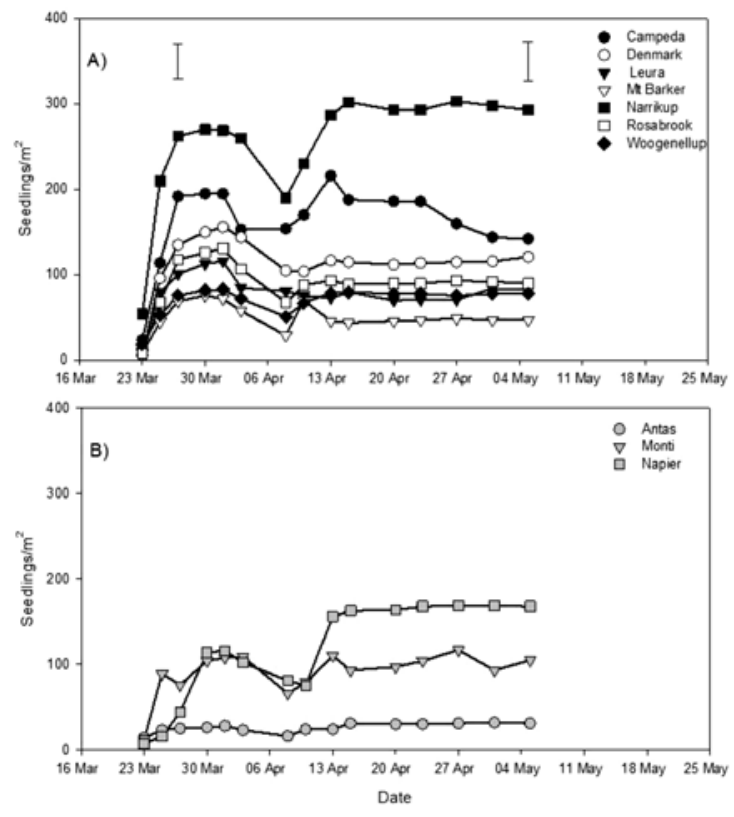

Figure $5 \quad$ Number of field emerged seedlings $/ \mathrm{m}^{2}$ of 10 subterranean clover cultivars, established in mixes with cocksfoot, from the first natural re-seeding following irrigation application of $25 \mathrm{~mm}$ on 10 March 2015 to ensure a strike. Error bars are SEM for the comparison of seedling numbers on 27 March 2015 and 5 May 2015 across all 10 cultivars. A) shows the seven subterraneum subspecies and B) shows the yanninicum and brachycalycinum subspecies.

To make definitive recommendations across the wide range of dryland environments in New Zealand much more information is required to determine the suitability of various sub clover cultivars. It is likely that funding for experiments comparing old and new cultivars over a large number of contrasting sites will be limited. In the meantime we shall have to rely on adapting Australian data to New Zealand conditions and interpreting farmer experience.

It is generally considered prudent to sow a mix of sub clover cultivars to cover site and seasonal climatic variability (Dear \& Sandral 1997), but it is also an important method for identifying which cultivars are best adapted to a specific environment. To this end, both farmers and their seed company field officers need to be able to identify resident sub clovers (often 'Mt Barker' or 'Tallarook') from each of the pair of cultivars which are sown. Farmers should request mixtures with two complementary sub clover cultivars for their autumn sowings. Pairs of cultivars may be medium versus late flowering, hard seeded versus soft seeded, winter active versus prostrate growth form, one "old" and proven cultivar paired with a newer "improved" cultivar, etc. If one cultivar is clearly dominant after 4 or 5 years then it can be assumed it is better adapted to that environment and management system.

Until more data are available on "new" cultivars we recommend that $5 \mathrm{~kg} / \mathrm{ha}$ of an older (pre-1998) proven cultivar, such as 'Denmark', should be mixed with $5 \mathrm{~kg} /$ ha of a newer (registered after 1998) cultivar.

\section{Conclusions}

- Sub clover cultivars vary significantly and detailed research, plus records of farmer experience with new cultivars, is required before recommendations can be made with confidence for the range of New Zealand summer dry farming environments.

- Research priorities should include evaluating the importance of sub clover hardseededness under New Zealand conditions in relation to other characteristics such as flowering time and burr burial.

\section{ACKNOWLEDGEMENTS}

Phil Nichols, Department of Agriculture and Food, Western Australia, for valuable advice on sub clover cultivars. Malcolm Smith for management of the "MAXannuals" experiment and David Jack and Daniel Dash for assistance with the cocksfoot $\times$ sub clover cultivar experiment.

This work was funded as part of Phase II of the Pastoral 21 Programme, funded by the Ministry for Business, Innovation \& Employment; DairyNZ; Beef + Lamb NZ; and Fonterra and SFF Project 408090 "Sub 4 Spring".

\section{REFERENCES}

Bray, A.R.; Fraser, T.J.; King, W.M.; Mackay, A.D.; Moot, D.J.; Stevens, D.R. 2013. Pasture improvement needs and options for New Zealand sheep and beef farms. pp. 844-845 In: Proceedings of the 22nd International Grassland Congress. Revitalising Grasslands to Sustain our Communities, Sydney, Australia. New South Wales Department of Primary Industry, Kite St., Orange New South Wales, Australia.

Chapman, D.F.; Sheath, G.W.; MacFarlane, M.J.; Rumball, P.J.; Cooper, B.M.; Crouchley, G.; Hoglund, J.H.; Widdup, K.H. 1986. Performance of subterranean and white clover varieties in dry hill country. Proceedings of the New Zealand Grassland Association 47: 53-62.

Dear, B.S.; Sandral, G.A. 1997. Subterranean clover in NSW - identification and use. Agfact P 2.5.16. (2nd Ed.). Sydney: New South Wales Agriculture. 36 pp.

Dodd, M.B.; Sheath, G.W.; Richardson, S. 1995a. Development of subterranean clover (Trifolium subterraneum L.) genotypes for New Zealand pastures. 1. Whatawhata persistence evaluation. New Zealand Journal of Agricultural Research 38: 33-47. 
Dodd, M.B.; Sheath, G.W.; Tarbotton, I.S. 1995 b. Development of subterranean clover (Trifolium subterraneum L.) genotypes for New Zealand pastures. 3. Whatawhata production evaluation. New Zealand Journal of Agricultural Research 38: 57-63.

Levy, E.B.; Gorman, L.W. 1936. Strain in subterranean clover. Proceedings of the New Zealand Grassland Association 5: 19-30.

Macfarlane, M.J.; McGowan, A.W.; Sheath, G.W.; Korte, C.J. 1990. An on-farm evaluation of white and subterranean clovers in North Island hill country. Proceedings of the New Zealand Grassland Association 51: 157-161.

Macfarlane, M.J.; Sheath, G.W. 1984. Clover - What types for dry hill country? Proceedings of the New Zealand Grassland Association 45: 140-150.
Nichols, P.G.H.; Foster, K.J.; Piano, E.; Pecetti, L.; Kaur, P.; Ghamkhar, K.; Collins, W.J. 2013. Genetic improvement of subterranean clover (Trifolium subterraneum L.). 1. Germplasm, traits and future prospects. Crop \& Pasture Science 64: 312-346.

Quinlivan, B.J.; Millington, A.J. 1962. The effect of a Mediterranean summer environment on the permeability of hard seeds of subterranean clover. Australian Journal of Agricultural Economics 13: 377-387.

Smetham, M.L. 2003. Subterranean clover (Trifolium subterraneum): its history and current and future research in New Zealand. Legumes for Dryland. Grassland Research and Practice Series 11: 61-72.

Widdup, K.H.; Pennell, C. 2000. Suitability of new subterranean clovers in the Canterbury region. Proceedings of the New Zealand Grassland Association 62: 161-165. 